\title{
ESTUARY NIDA RIVER - CARTOGRAPHIC AND GEOMORPHOLOGICAL CHANGES - FIRST RESULTS
}

DOI: https://doi.org/10.18509/AGB.2021.06

UDC: 556.54:551.4]:528.9(438)

\section{Piotr Biesaga, Tomasz Kalicki}

Institute of Geography, and Environmental Sciences Jan Kochanowski University in Kielce, Poland

\author{
corresponding author: biesaga.piotr@onet.pl
}

submitted: 16.04 .2020

accepted: 28.06 .2020

published: 30.09 .2020

\begin{abstract}
Cartographic data has allowed to state very large changes in the estuary of the Nida, as well as the Vistula riverbed in the last 250 years. They were both natural and anthropogenic changes. The studied section is distinguished from other sections of Nida by the lack of organic sediments within the flood plain. The floodplain probably consists of two different-age cut and fill. The older ones, in the marginal part, build sands with a normal sequence. The younger ones, near the riverbed, build coarser alluvia with an coarseing upward sequence. These differences in the geological structure testify to an increase of fluvial processes dynamic what can be related to anthropopressure in the Nida basin in last centuries
\end{abstract}

Keywords: Nida River valley, Nida estuary, cartographic changes, geological changes

\section{INTRODUCTION}

The research area (Fig. 1) is located in the Nida Valley mesoregion (342.25) which is part of the Nida Trough (342.2) located in the Lesser Poland Upland (342), and this is located in the Polish Uplands (34) [1]. The Nida Trough is a wide depression of the area between the Kielce Upland and the Silesian-Krakow Upland. Remnants of the Pleistocene glacial deposits are currently preserved only in relief depressions and on hill slopes. The Holocene is represented by alluvium in the river valleys, slope deposits and alluvial fans up to $10 \mathrm{~m}$ thick and small peat bogs (up to about $1 \mathrm{~m}$ thick) in river valleys [2]. The research area includes a reach about $20 \mathrm{~km}$ long - an estuary valley of the Nida river and a fragment of the Vistula river flood plain in the region Stary and Nowy Korczyn. Left slope of the valley built of fluvial deposits with marl outcrops is flattened and much gentler than the steep right slope built of the Vistulian loess [3], [4]. Nowadays, Nida river flows into the Vistula river east of Nowy Korczyn in the Podraje village.

The first mentions of Stary Korczyn are from the 12th century. In 1226 Polish King Bolesław Wstydliwy was born there, who in 1258 located the New Town of Korczyn under Magdeburg law. It became an important administrative center and one of the very popular seats of Polish kings. Due to their location, not only land roads but also frequented water routes led to these towns. Granaries were located in the fork of the Nida and the Vistula rivers, as the map from the end of the 18th century shows (Fig. 2). 


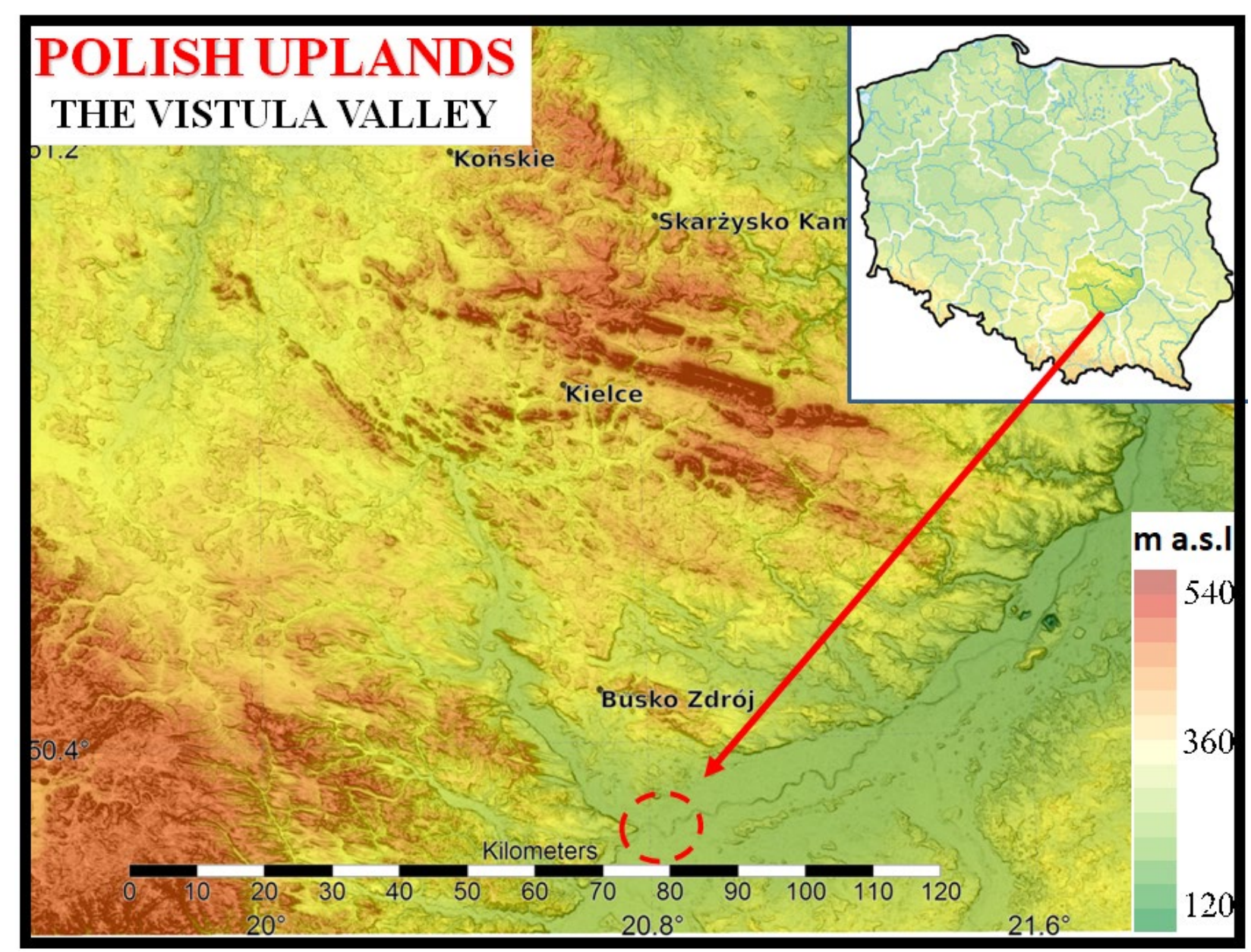

Figure 1. Location of the study area on DEM (by Frączek 2017).

\section{AIM OF STUDY AND METHODS}

The purpose of the work was to recognize changes in the river network based on cartographic and geological data. For this purpose collected and historical maps were analyzed from the end of the 18th century. To determine the location changes of the Nida river estuary to the Vistula river in historical times the following maps were analyzed:

- Special mappa of the Sandomierz Province (1: $225000 \mathrm{~K}$. de Perthées, detailed provincial maps),

- Heldensfeld-Benedicti: Carte von WestGallizien 1:288 000 from 1808,

\section{RESULTS}

In the end of 18th century (Fig. 2) many midchannel bar in the meandering Vistula rivebed occurred. It may indicate a tendency to braided pattern. Natural Nida's riverbed divide into several arms (channels) just before connected to the Vistula river. However, the natural Nida riverbed (marked on the map*) was anthropogenically cut
- Map from 1864. Sheet New Town Korczyn Quartermaster General of the Polish Army,

- Map of 1915 Gruppe Warschau (1:25 000).

As part of chamber works, published and unpublished geological, topographic and hydrographic materials were collected. The cartographic image has been verified by geological surveys. Six geological borehole drillings and grain size analyses by sieve method were made. A sieve set from $2.8 \mathrm{~mm}$ to $63 \mu \mathrm{m}$ was used. Graphic results were made in the GRANULOM program.

off, and as a result the river length increased. New Nida riverbed (marked on the map**) is visible both west (Leka) and east (Grotniki-Pawłow) of Nowy Korczyn. In addition, anthropogenic channel has been clearly marked from the Vistula riverbed to the new Nida riverbed in Nowy Korczyn. 


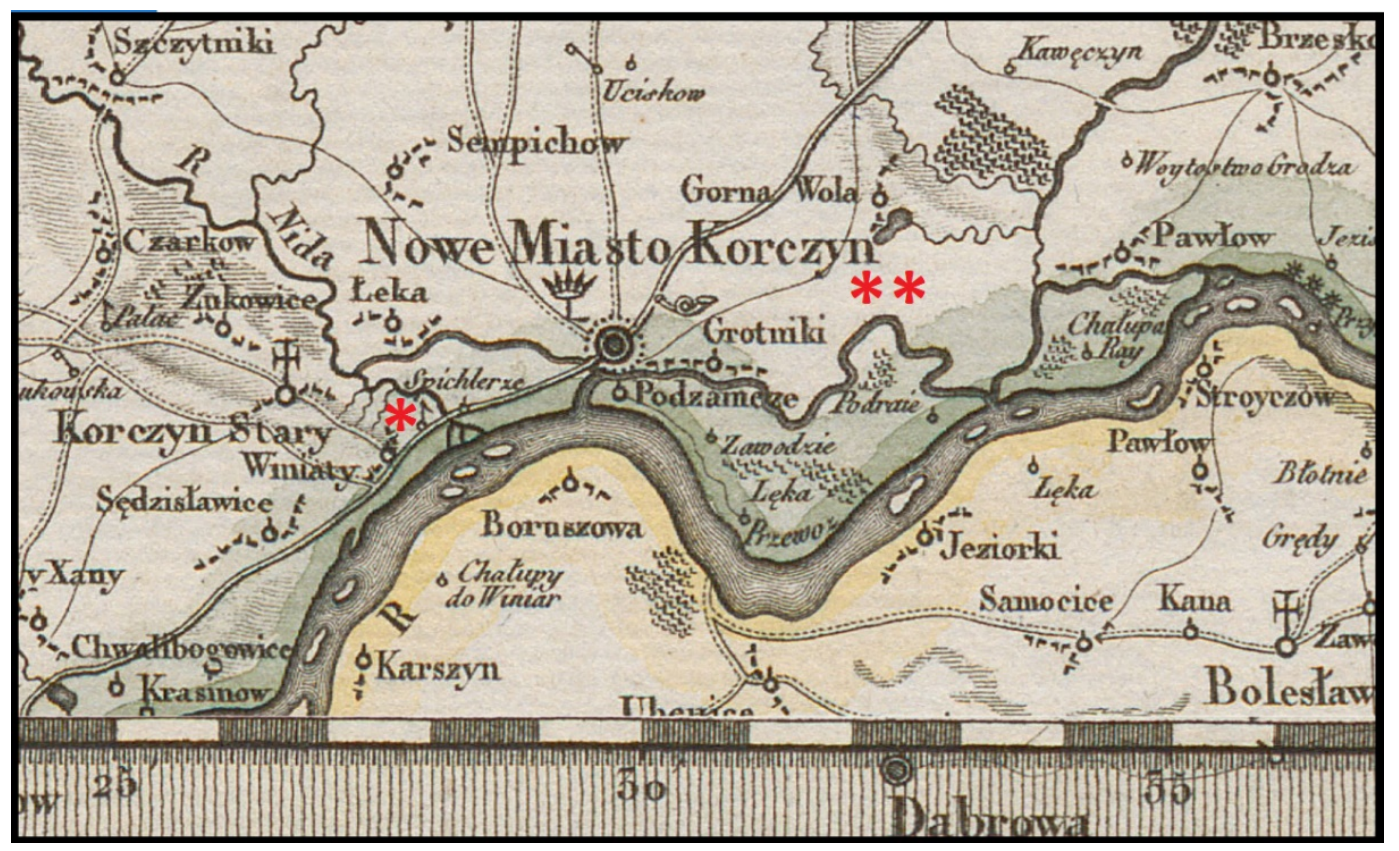

Figure 2. Special mappa of the Sandomierz Province

1: 225000 K. de Perthées, detailed provincial maps) from 1797.

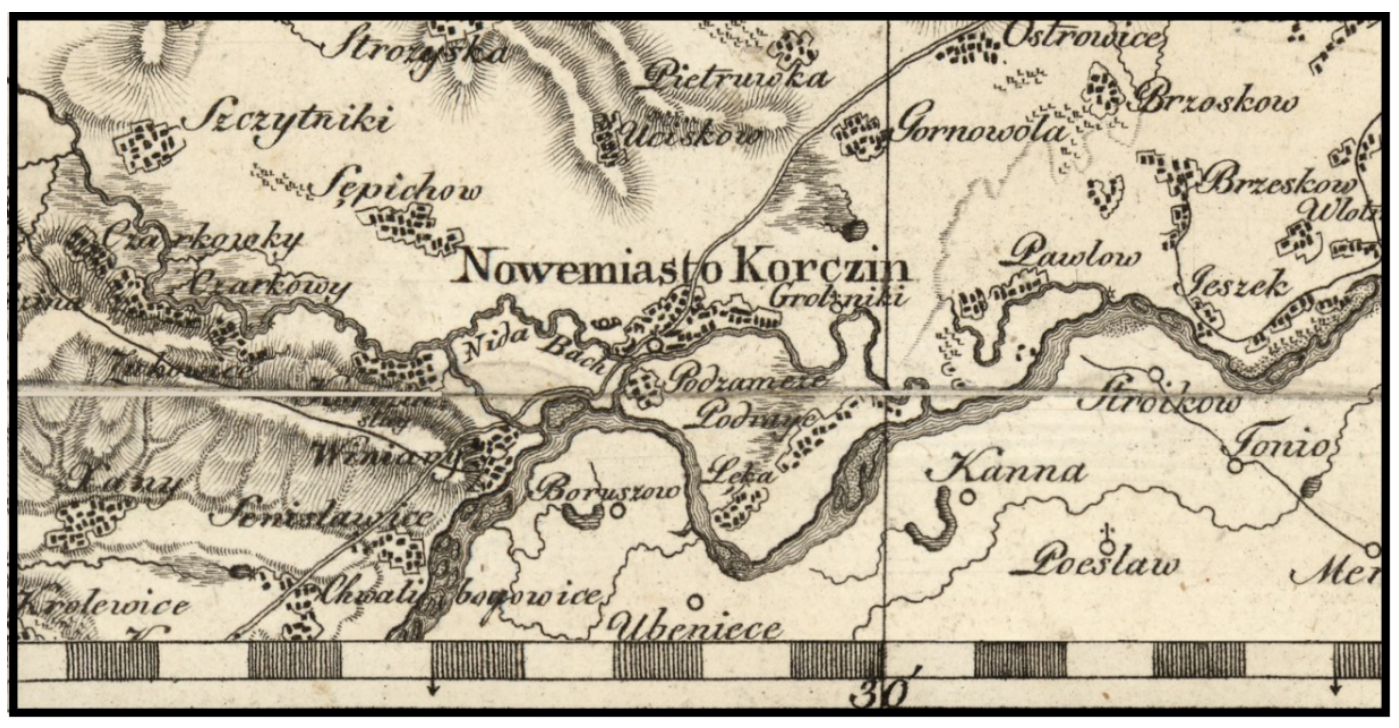

Figure 3. Heldensfeld-Benedicti: Carte von West-Gallizien 1:288 000 from 1808.

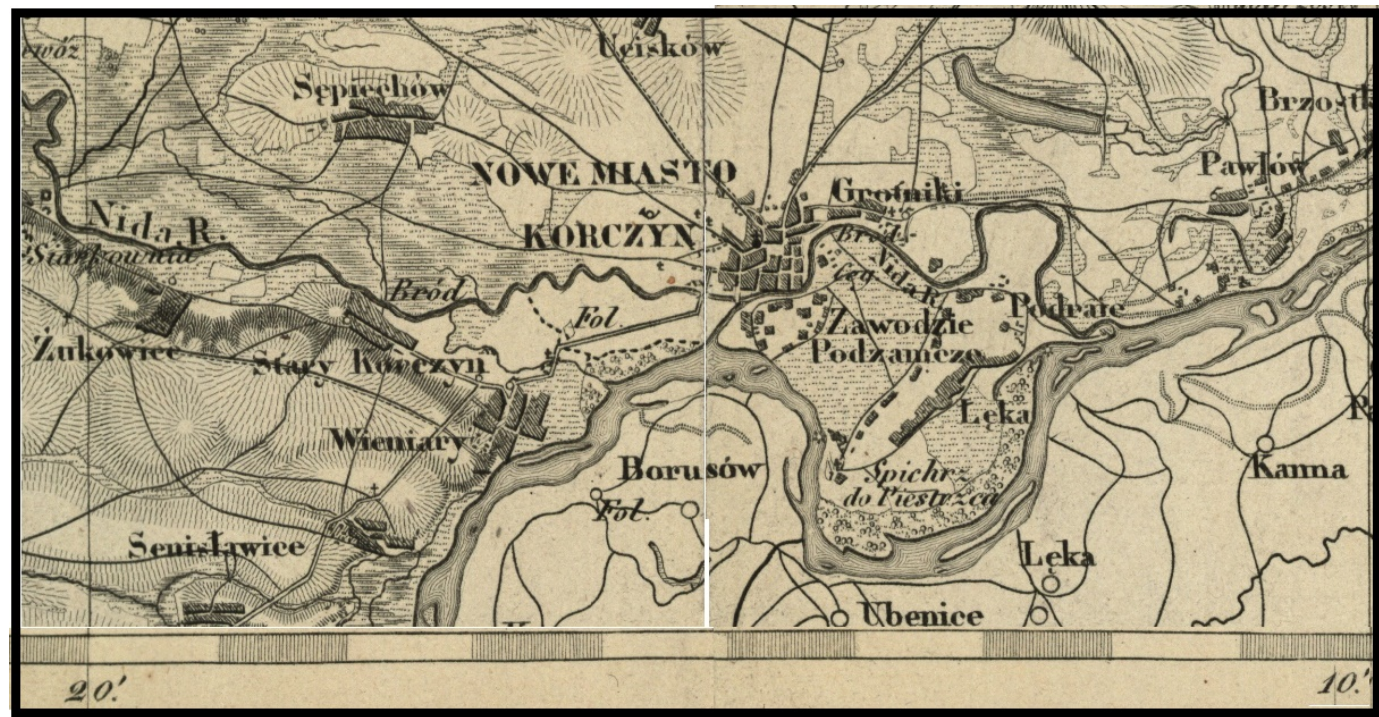

Figure 4. Map from 1864. Sheet New Town Korczyn Quartermaster General of the Polish Army 


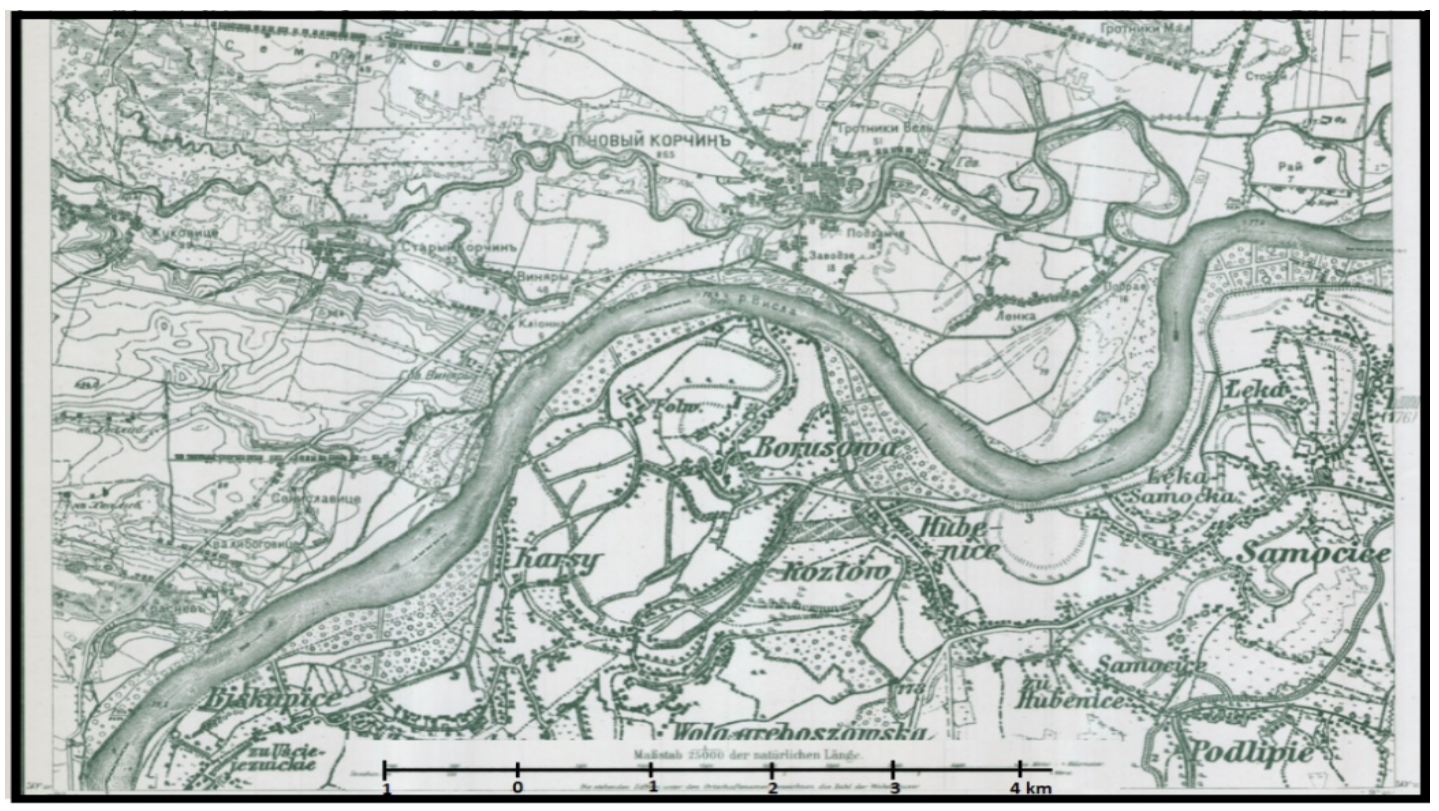

Figure 5. Osteuropa in 1915 1:25 000 - German maps of the Russian partition, WWI.

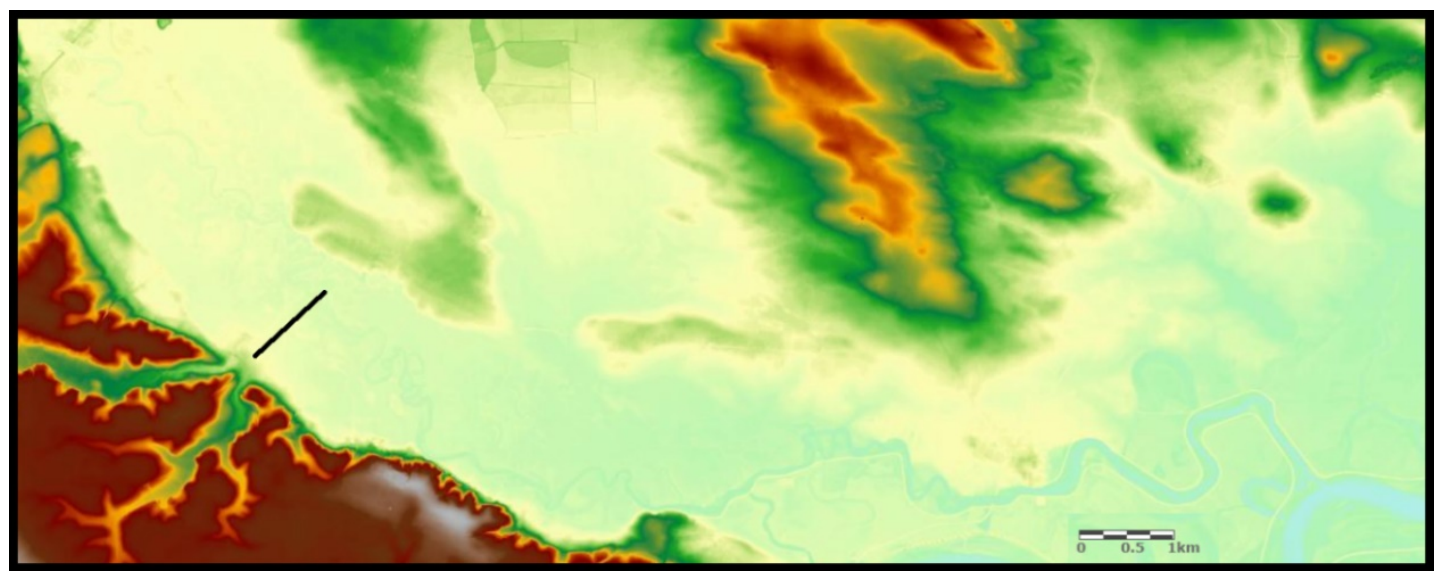

Figure 6. DEM marked course of the cross-section "Pisarka". (source geoportal.gov)

On the map from 1808 (Fig. 3) one can see the "renovated" riverbed of Nida. It follows that Nida has returned to her natural riverbed. Delta or a large mid-channel bar occurred in estuary of the Nida river into the Vistula river. However, the most eastern section of the Nida riverbed near Pawłów was abandoned and became an oxbow lake. This shortened the course of the river.. On the map from 1864 (Fig. 4), in the place of the natural Nida riverbed a small channel was marked and the main river course was directed to the east. The estuary is shown in the same place like today. The easternmost channel near Pawłów was completely abandoned. The pattern of mid channel-bar of the Vistula river changed - which are narrower and there are fewer of them, but they are located in similar places what on previous maps (Fig. 2, Fig. 3). The map from 1915 (Fig. 5) shows a lot of changes within the Vistula riverbed which was regulated in the second half of the 19th century and the mid channel bar are almost gone. Nida river was also regulated. Its right riverbank has been regulated and embanked from the estuary to the town of Stary Korczyn, while on the left riverbank the embankment extends from the estuary to Nowy Korczyn. In addition, the anthropogenic channel from the Vistula to Nowy Korczyn was decommissioned removed during the regulation of the Vistula. As a result of the regulation of the Nida river, the former, natural riverbed was completely cut off, and Winiary village was built over this oxbow lake. The geological structure of the floodplain was also recognized in the most NE part of the estuary section of the Nida river valley Pisarka cross-section (Fig. 6). Within it two cut and fill could be distinguished differing in structure and sequence of layers. In the SW part, the most distant from the modern Nida riverbed (borehole 2, 3, 4) (Fig.7) there is a cut and fill with fining upward (normal) sequence typical for alluvia of meandering river. At the bottom, gravels were deposited, moving upwards into medium and fine sands. Closer to the present-day Nida river, the alluvium has an inverted (coarsening upward) sequence. (Fig.7). 


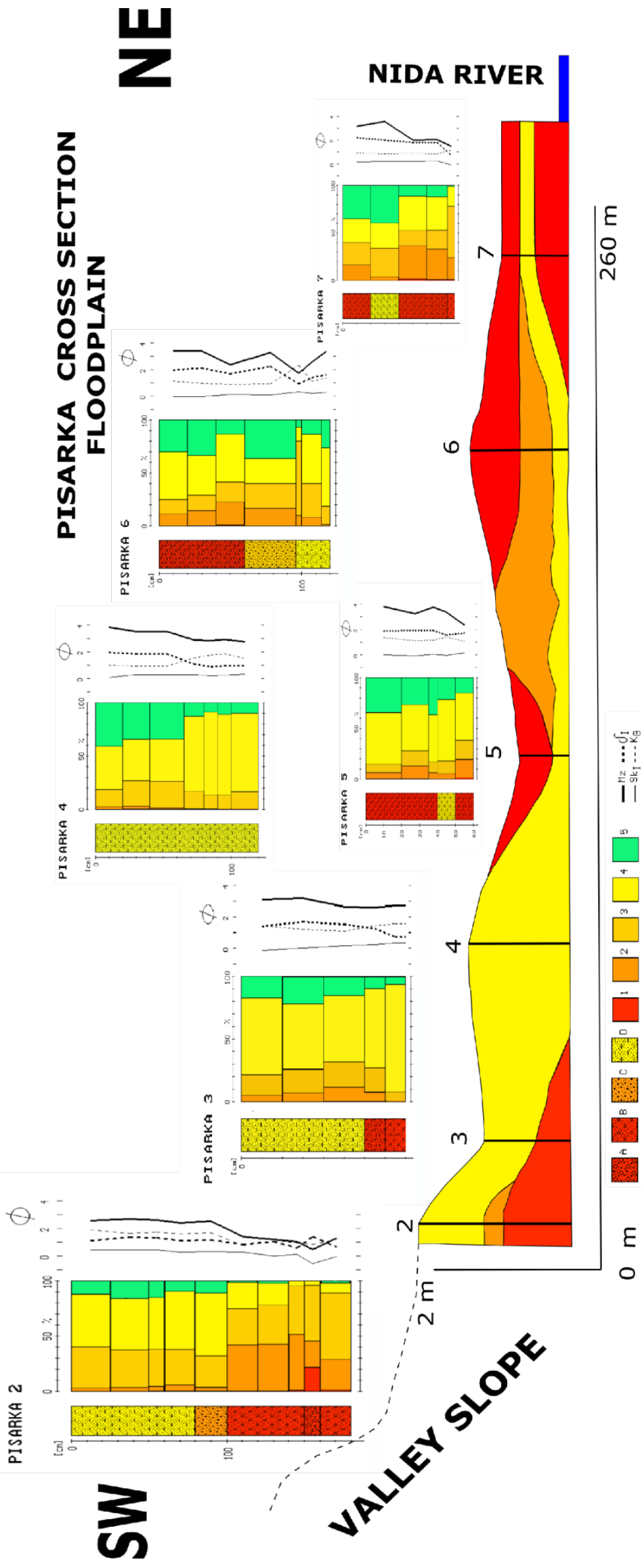

Figure 7. Schematic section across the Nida flood plain with grain size of sediments in study borings Lithology: A-sands with gravels, B-sands with single gravels, C-coarse sands, D-silty sands;

Fractions: 1 - gravel (below $-1 \varphi) ; 2$ - coarse sand $(-1-1 \varphi), 3$ - medium sand $(1-2 \varphi)$, 4 - fine sand $(2-4 \varphi)$, 5 - silt and clay (above $4 \varphi$ ); Folk-Ward's grain size distribution parameters:

$\mathrm{Mz}$ - mean size, $\delta \mathrm{I}$ - standard deviation, SkI - skewness, KG - kurtosis. 


\section{DISCUSSION AND CONCLUSIONS}

The cartographic data show very large changes in the estuary of the Nida river as well as the Vistula riverbed in the last 250 years. They were both natural and anthropogenic changes. The first of them includes occurrence of mid-channel bars in the Vistula riverbed on every maps (fig. 2, fig. 3, fig. 4, fig. 5) which indicates a tendency to braided pattern. This is in line with Falkowski's hypothesis [5] on the change in the development of the rivers from meandering to braided in the last centuries due to the destruction of the anthropogenic small retention water system. The channel made from the Vistula to Nowy Korczyn can be considered as distinct anthropogenic change. The final section of Nida river is presented in various ways as one, two or three riverbeds and mouths. One of them looks as "cut off" during the works regulating the right bank of the Nida river. Today, in the place of the abandoned channel, there are residential buildings at Winiary (fig. 5). Human interference has also lengthened the course of Nida in the last centuries. The examined section stands out from other sections of the Nida river valley through organic sediments within the floodplain comparison to other reaches [6], [7], [8], [9],[10]. The floodplain probably consists of two different-age cut and fill. The older one, in the marginal part, build sands with a normal sequence. The younger one, near the present-day riverbed, buildcoarser sediments with an inverted sequence (fig. 7) These differences in the geological structure testify to the intensity increase of fluvial processes which is associated with anthropopressure in the Nida river basin in the last centuries.

\section{REFERENCES}

[1] Kondracki J. Geografia regionalna Polski. PWN Warszawa: pp. 1 - 468, 2002.

[2] Łyczewska J. Czwartorzęd regionu świętokrzyskiego (The Quatenary of the Góry świętokrzyskie region). - Prace Inst. Geol., vol. 64. Warszawa, Poland, pp. 5-108, 1971.

[3] Lyczewska J. Niektóre problemy czwartorzędu regionu świętokrzyskiego (Problems of Quatemary Investihations on the Hely Cross Mts.). - Rocz. P. T. Geol. (Ann. Soc. Geol. Pol.), vol. 42, no. 1. Kraków, Poland, pp. 83 - 92,1972.

[4] Lindner L. Plejstocen północno-zachodniego obrzeżenia gór Świętokrzyskich (Pleistocene of the north-western margin of the Holy Cross Mts.). Rocz. Pol. Tow. Geol. 42, nr 1, Kraków, Poland, pp. 117 - 124, 1972

[5] Falkowski E. Some regularities of the valley floor evolution of the Middle Vistula River valley. In: Evolution of the Vistula River valley during the last 15000 years. Ed. L. Starkel. IGiPZ PAN, Warszawa, Poland, pp. $9-20,1982$

[6] Mityk J. Zarys rzeźby terenu badanego odcinka zlewni Nidy. Studia kieleckie 1/61, Kielce, Poland, pp. 21 - 30, 1989.

[7] Kalicki T., Frączek M., Stępień K., Zaborska D., Malęga E., Leśniewski F., Biesaga P. Osady i procesy fluwialne Nidy zapisane w profilach równiny zalewowej koło Brzegów (Niecka Nidziańska), Sbornik abstrakt 21. Kvarter (eds. H. Nohalova, V. Káňa, J. Březina), 27.11.2014, Brno, Czechy, pp. 22, 2015.

[8] Kalicki T., Maciszewski I., Frączek M., Stępień K., Zaborska D., Kusztal P., Nowak M. Geoarchaeological studies near Brzegi in Nida river valley (Polish Uplands), 12 Konference Environmentalni Archeologie „Před neolitem...”, 7-9.02.2016, Praga, Czechy, pp. 30, 2016.

[9] Sołtysik R. Geneza mokradeł Gór Świętokrzyskich i Niecki Nidziańskiej. Prace Inst. Geogr. AŚ w Kielcach 9, Kielce, Poland, pp. 1-126, 2002.

[10] Walczyńska K., Tomczyk M., Kalicki T., Frączek M. Geomorphological and morphodynamic mapping of the Nida valley near Stawy, Sbornik abstraktů 24. Kvarter (eds. L. Kleprliková, J. Šamánek, T. Turek, G. Calábková, Martin Ivanov), 30.11.2018, Brno, Czechy, pp. 69, 2018. 